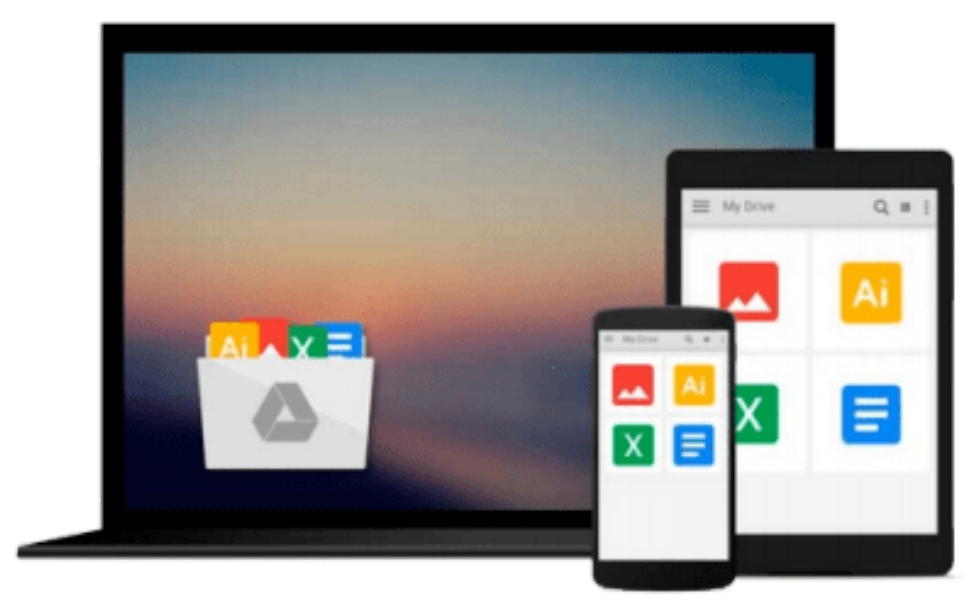

Nudge: Improving Decisions About Health, Wealth, and Happiness Revised \& Expanded Edition by Thaler, Richard H., Sunstein, Cass R. published by Penguin Books (2009)

\title{
Download now
}

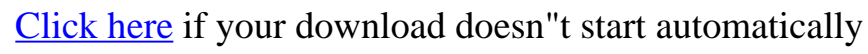




\section{Nudge: Improving Decisions About Health, Wealth, and Happiness Revised \& Expanded Edition by Thaler, Richard H., Sunstein, Cass R. published by Penguin Books (2009)}

Nudge: Improving Decisions About Health, Wealth, and Happiness Revised \& Expanded Edition by Thaler, Richard H., Sunstein, Cass R. published by Penguin Books (2009)

๖ Download Nudge: Improving Decisions About Health, Wealth, a ...pdf

目 Read Online Nudge: Improving Decisions About Health, Wealth, ...pdf 


\section{Download and Read Free Online Nudge: Improving Decisions About Health, Wealth, and Happiness Revised \& Expanded Edition by Thaler, Richard H., Sunstein, Cass R. published by Penguin Books (2009)}

\section{From reader reviews:}

\section{Nicole Marcil:}

Nowadays reading books become more than want or need but also get a life style. This reading routine give you lot of advantages. The advantages you got of course the knowledge the particular information inside the book that improve your knowledge and information. The knowledge you get based on what kind of book you read, if you want have more knowledge just go with education books but if you want experience happy read one with theme for entertaining such as comic or novel. The particular Nudge: Improving Decisions About Health, Wealth, and Happiness Revised \& Expanded Edition by Thaler, Richard H., Sunstein, Cass R. published by Penguin Books (2009) is kind of reserve which is giving the reader unstable experience.

\section{Carol Reck:}

Reading can called head hangout, why? Because if you are reading a book specially book entitled Nudge: Improving Decisions About Health, Wealth, and Happiness Revised \& Expanded Edition by Thaler, Richard H., Sunstein, Cass R. published by Penguin Books (2009) the mind will drift away trough every dimension, wandering in most aspect that maybe unknown for but surely will end up your mind friends. Imaging each word written in a book then become one contact form conclusion and explanation in which maybe you never get prior to. The Nudge: Improving Decisions About Health, Wealth, and Happiness Revised \& Expanded Edition by Thaler, Richard H., Sunstein, Cass R. published by Penguin Books (2009) giving you another experience more than blown away your thoughts but also giving you useful data for your better life in this era. So now let us explain to you the relaxing pattern is your body and mind is going to be pleased when you are finished studying it, like winning a. Do you want to try this extraordinary paying spare time activity?

\section{Sarah Petty:}

Your reading sixth sense will not betray a person, why because this Nudge: Improving Decisions About Health, Wealth, and Happiness Revised \& Expanded Edition by Thaler, Richard H., Sunstein, Cass R. published by Penguin Books (2009) publication written by well-known writer who knows well how to make book which can be understand by anyone who have read the book. Written with good manner for you, still dripping wet every ideas and creating skill only for eliminate your hunger then you still hesitation Nudge: Improving Decisions About Health, Wealth, and Happiness Revised \& Expanded Edition by Thaler, Richard H., Sunstein, Cass R. published by Penguin Books (2009) as good book not only by the cover but also by content. This is one book that can break don't evaluate book by its include, so do you still needing an additional sixth sense to pick this kind of!? Oh come on your looking at sixth sense already alerted you so why you have to listening to one more sixth sense.

\section{Jerry Ingle:}

What is your hobby? Have you heard this question when you got learners? We believe that that concern was 
given by teacher to the students. Many kinds of hobby, All people has different hobby. And you know that little person just like reading or as reading become their hobby. You must know that reading is very important along with book as to be the issue. Book is important thing to include you knowledge, except your teacher or lecturer. You get good news or update regarding something by book. Amount types of books that can you decide to try be your object. One of them is this Nudge: Improving Decisions About Health, Wealth, and Happiness Revised \& Expanded Edition by Thaler, Richard H., Sunstein, Cass R. published by Penguin Books (2009).

\section{Download and Read Online Nudge: Improving Decisions About Health, Wealth, and Happiness Revised \& Expanded Edition by Thaler, Richard H., Sunstein, Cass R. published by Penguin Books (2009) \#3KT0YXRU7DS}




\section{Read Nudge: Improving Decisions About Health, Wealth, and Happiness Revised \& Expanded Edition by Thaler, Richard H., Sunstein, Cass R. published by Penguin Books (2009) for online ebook}

Nudge: Improving Decisions About Health, Wealth, and Happiness Revised \& Expanded Edition by Thaler, Richard H., Sunstein, Cass R. published by Penguin Books (2009) Free PDF d0wnl0ad, audio books, books to read, good books to read, cheap books, good books, online books, books online, book reviews epub, read books online, books to read online, online library, greatbooks to read, PDF best books to read, top books to read Nudge: Improving Decisions About Health, Wealth, and Happiness Revised \& Expanded Edition by Thaler, Richard H., Sunstein, Cass R. published by Penguin Books (2009) books to read online.

Online Nudge: Improving Decisions About Health, Wealth, and Happiness Revised \& Expanded Edition by Thaler, Richard H., Sunstein, Cass R. published by Penguin Books (2009) ebook PDF download

Nudge: Improving Decisions About Health, Wealth, and Happiness Revised \& Expanded Edition by Thaler, Richard H., Sunstein, Cass R. published by Penguin Books (2009) Doc

Nudge: Improving Decisions About Health, Wealth, and Happiness Revised \& Expanded Edition by Thaler, Richard H., Sunstein, Cass R. published by Penguin Books (2009) Mobipocket

Nudge: Improving Decisions About Health, Wealth, and Happiness Revised \& Expanded Edition by Thaler, Richard H., Sunstein, Cass R. published by Penguin Books (2009) EPub 